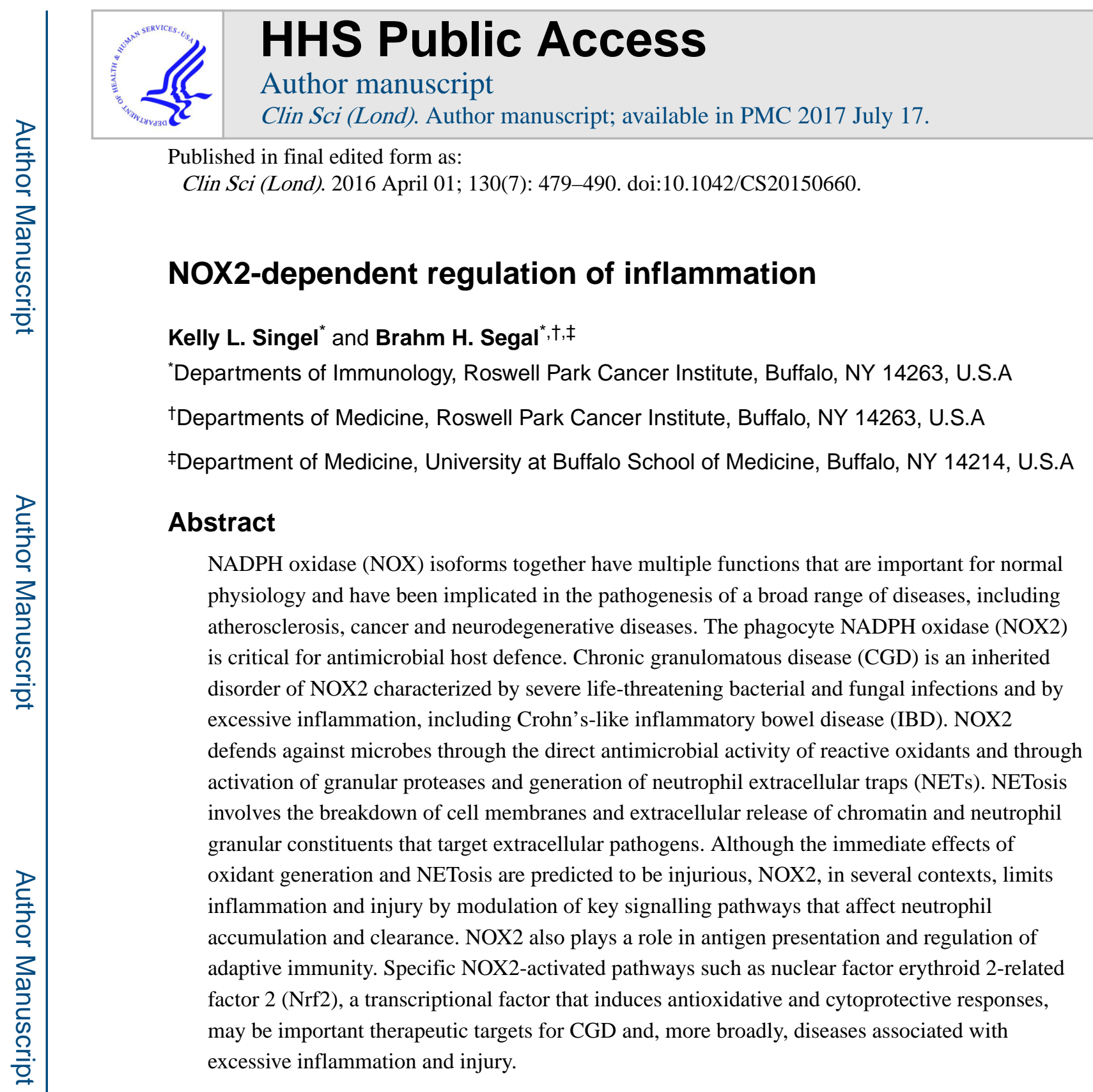

\title{
Keywords
}

host defence; inflammation; NADPH oxidase; NOX2

\section{THE NADPH OXIDASE FAMILY}

A large family of NADPH oxidases (NOX) has been identified in plants, fungi, invertebrates and higher animals. As an example, Drosophilae harbour a dual oxidase (DUOX) homologue in intestinal epithelia that mediates gut antimicrobial host defence [1,2]. Seven members of the NOX family have been characterized (e.g. NOX1-5 and DUOX 1 and 2). NOX homologues have the following characteristics [3]: six transmembrane spanning domains (or seven for DUOX homologues); two haem-binding sites; one cytoplasmic

Correspondence: Brahm H. Segal (brahm.segal@ roswellpark.org). 
NADPH-binding site and sequence similarity. These NOX isoforms are expressed in numerous cell types and have diverse physiological functions. NOX2 is the isoform found in professional phagocytes (e.g. eosinophils, macrophages and neutrophils) [4] and dendritic cells [5,6]. Several of the nonphagocyte NOX enzymes, such as those expressed on epithelial surfaces, also probably have host defence functions [7].

The phagocyte NADPH oxidase (NOX2) is a crucial enzyme in antimicrobial host defence and in regulating inflammation. Patients with chronic granulomatous disease (CGD), an inherited disorder of NOX2 in which phagocytes are defective in generation of reactive oxidant intermediates (ROI), suffer from life-threatening bacterial and fungal infections [8]. Among CGD patients, the degree of impairment of NOX2 in neutrophils correlates with mortality [9]. NOX2 is rapidly activated by conditions that, in nature, are associated with infectious threat, such as ligation of specific pathogen recognition receptors (PRR) by microbial products (e.g. formylated peptides and fungal cell wall $\beta$-glucans), opsonized particles and integrin-dependent adhesion $[6,10,11]$. Activation of NOX2 requires translocation of cytoplasmic subunits $\mathrm{p} 40^{\text {phox }}, \mathrm{p} 47^{\text {phox }}$ and $\mathrm{p} 67^{\text {phox }}$ and Rac to a membranebound heterodimer cytochrome comprised of gp91 ${ }^{\text {phox }}$ and p22 $2^{\text {phox }}$ (Figure 1). Molecular oxygen is converted to superoxide anion, which can be converted to downstream metabolites with antimicrobial activity, including $\mathrm{H}_{2} \mathrm{O}_{2}$ and hydroxyl anion. In neutrophils, myeloperoxidase (MPO) converts $\mathrm{H}_{2} \mathrm{O}_{2}$ to hypohalous acid, a potent microbicidal metabolite [12-14].

Although the early effects of NOX2 activation - ROI generation, protease activation and neutrophil extracellular trap (NET) generation - are expected to be pro-inflammatory and injurious, observation of CGD patients and experimental models of NOX2 deficiency point to a more complex role for NOX2 in inflammation and injury. In addition to recurrent infections, CGD patients suffer from excessive inflammatory responses. About one-third of CGD patients develop Crohn's-like inflammatory bowel disease (IBD) [15]; other manifestations of excessive inflammation include granulomatous involvement of the genitourinary tract that can lead to obstruction, sarcoid-like lung inflammation and surgical wound dehiscence $[8,16,17]$. Although this excessive inflammation was thought to result from unresolved infection, work over several decades has shown that NOX2 has a major role in calibrating immune responses in addition to protecting from infection. NOX2 can, in fact, limit inflammation and injury by modulation of key signalling pathways that affect neutrophil accumulation and clearance, as well as adaptive immunity.

Our goals are to discuss the mechanisms by which NOX2 mediates host defence and coordinates the inflammatory response. This knowledge may set the foundation for novel therapeutic approaches in CGD and, more broadly, for diseases associated with excess inflammation and injury.

\section{NOX2 in MACROPHAGES}

Alveolar macrophages are the first-line phagocytes that respond to inhaled pathogens (Figure 2). They phagocytose and kill microbes and also coordinate the inflammatory response. Macrophages, neutrophils, and dendritic cells sense microbial motifs through 
PRR, such as toll-like receptors, nucleotide-oligomerization domain (NOD)-like receptors and C-type lectin receptors. In addition to microbial products, endogenous products of necrosis, termed damage-associated molecular patterns (DAMPs), activate innate immune responses through pathways that are similar to those engaged by microbes.

Although it is well established that NOX2 is critical for neutrophil-mediated host defence, the importance of NOX2 in macrophages is less established. The strongest evidence for the role of macrophage NOX 2 in host defence is from the finding that mutations in gp $91^{\text {phox }}$ that selectively affect macrophages lead to increased susceptibility to mycobacterial diseases [18]. Prior studies have shown that alveolar macrophages ingest and kill Aspergillus spores, whereas neutrophils principally target the hyphal stage [19]. However, there have been conflicting results as to the role of macrophage NOX2 in controlling the growth of Aspergillus fumigatus spores [20,21]. Using knockin transgenic mice with NOX2 selectively reconstituted in the monocyte/macrophage and dendritic cell lineages, Grimm et al. [22] showed that macrophage NOX2 was protective against pulmonary challenge with $A$. fumigatus, and limited the germination of phagocytosed spores in isolated alveolar macrophages. These knockin mice have a naturally-acquired disabling mutation of Ncf1 (which encodes the $\mathrm{p} 47^{\text {phox }}$ protein) and harbour a transgene containing wild-type $N c f 1$ under the control of a human CD68 promoter [23]. These knockin mice were also more resistant to Staphylococcus aureus and Burkholderia cepacia infections compared with NOX2-deficient mice [24]. Together, these results show an important role for macrophage NOX2 in host defence.

\section{NOX2 IN NEUTROPHILS}

Following recruitment to sites of infection or damage, activated neutrophils kill microbes through oxidant-dependent and -independent pathways. The rapid activation of NOX2 in neutrophils constitutes an emergency response to invading pathogens. Neutrophil NOX2 activation occurs in response to several stimuli such as opsonized particles, integrindependent adhesion [10,25] and ligation of specific PRR (e.g. Dectin-1 [11]). The Syk tyrosine kinase is a critical component of integrin signalling in neutrophils, including NOX2 activation $[10,25,26]$. NOX2 embedded in the plasmamembrane releases ROI into the extracellular environment whereas NOX2 in neutrophil secondary granules targets phagocytosed pathogens.

Kuhns et al. [9] showed that residual NOX2 activity in neutrophils from CGD patients was associated with less severe illness and a greater likelihood of long-term survival than patients with little or no NOX2 function. This effect on survival was observed in both X-linked and autosomal recessive forms of CGD. These results demonstrate that even low residual levels of NOX2 activity in neutrophils are protective, and support the notion that a small proportion of NOX2-competent neutrophils that may be achievable with gene therapy will reduce infection risk in CGD patients.

CGD patients are at high risk for a limited spectrum of pathogens [27,28], highlighting the fact that pathogens have varying sensitivity to NOX2-dependent host defence. As an example, neutrophils inhibit $A$. fumigatus conidial growth by lactoferrin-mediated iron 
depletion, whereas inhibition of growth of hyphae (the tissue-invasive stage of filamentous fungi) required NOX2 [29]. In ex vivo studies, NOX2 in neutrophils and peripheral blood mononuclear cells (PBMCs) was required for killing A. fumigatus, but not Aspergillus nidulans [30]. A. nidulans is a major pathogen in CGD patients [31], pointing to the fact that absence of the direct microbicidal effect of ROI observed ex vivo does not explain the host defence defect observed in the clinic. Olfactomedin 4 (OLFM4) is a neutrophil granule protein that inhibits host defence against bacterial infection. Olfm 4 deletion augmented defence against $S$. aureus, but not against $A$. fumigatus, in NOX2-deficient mice [32]. Together, these findings demonstrate a complex interaction of NOX2 and ROI-independent pathways in neutrophil-mediated host defence in which NOX2 is required for defence against certain pathogens while being dispensable for others.

\section{ACTIVATION OF NEUTROPHIL PROTEASES AND NEUTROPHIL EXTRACELLULAR TRAPS}

In neutrophils, the NOX2-MPO system exerts direct antimicrobial effects through oxidative damage. In addition, NOX2 activation in neutrophils can further augment host defence by activation of granular proteases and generation of NETs (Figure 2). NOX2 activation leads to alkalinization of phagosomes, and normalization of phagocytic $\mathrm{pH}$ in CGD phagocytes increased the ability to kill $S$. aureus [33]. NOX2 activation is accompanied by an influx of $\mathrm{K}^{+}$ions and a rise in $\mathrm{pH}$, which, in turn, is linked to activation of primary granular proteases that are predicted to enhance intracellular killing [34]. In support of this model, chloroquine, a lysosomotropic agent that prevents endosomal acidification, increased the antifungal activity of neutrophils from CGD patients [35].

In a landmark study, Brinkmann et al. [36] showed that neutrophils are capable of releasing extracellular traps that target extracellular bacteria. NETosis is triggered as a response to infection and to conditions mimicking sepsis [37,38]. In contrast with necrosis and apoptosis, nuclear decondensation and breakdown of the nuclear and granular membranes are unique features of NETosis [39]. NETs are characterized and visualized by extracellular stretches of chromatin that co-localize with cytosolic and granular proteins [39-41]. NETs can mediate host defence through a number of pathways, including binding to microbes preventing dissemination, degrading pathogen virulence factors and killing of pathogens $[36,42,43]$. A number of NET constituents (e.g. histones, serine proteases) have antimicrobial activity. MPO, following release with NET formation, can generate hypohalous acid directed at extracellularmicrobes [44]. Calprotectin is a NET constituent that mediates nutritional immunity by sequestering divalent metal ions and targets Candida and Aspergillus species [45,46].

NOX2 activation is linked to NET generation. Administration of $\mathrm{H}_{2} \mathrm{O}_{2}$ and hypochlorous acid, which are metabolites generated by NOX2 activation, trigger NETosis [39,47,48]. Neutrophils from CGD patients are defective in NETosis and gene therapy resulted in restored NETosis in NOX2-competent neutrophils [43,46]. In pneumococcal lung infection, NETosis of bronchoalveolar lavage fluid (BALF)-recovered neutrophils was reduced, but not eliminated, in NOX2-deficient mice [49]. In this model, NOX2 may trigger NETosis directly 
or through stimulation of interferon- $\gamma$ (IFN- $\gamma$ ), which was shown to augment NETosis. In murine pulmonary aspergillosis, NOX2 was required for NET generation, which is posited to limit hyphal parenchymal invasion [41].

NOX2 can therefore target pathogens through a multi-step process: (i) direct killing from NOX2-MPO-generated ROI; (ii) activation of primary granular proteases that target phagocytosed pathogens and (iii) generation of NETs that target extracellular pathogens. Depending on the stimulus, NETs can also be induced by NOX2-independent pathways [5052]. Douda et al. [53] showed that NETosis can be activated by mitochondrial ROI independently of NOX2, through a pathway dependent on calcium-induced activation of SK3 (small conductance potassium channels) and Akt.

\section{MACROPHAGE AND NEUTROPHIL NOX2 COORDINATELY REGULATE ACUTE INFLAMMATION}

In addition to host defence, there is a growing body of evidence supportingNOX2 inmacrophages and neutrophils as critical modulators of inflammation. Neutrophils are rapidly recruited to sites of infection and trauma by activation of specific G-protein coupled receptors that are ligated by formylated peptides produced by bacteria and by host-derived chemoattractants, such as leukotriene B4, C5a, and chemokines [e.g. MIP-2 and interleukin (IL)-8]. Activation of specific PRR generally leads to nuclear factor kappa-light-chainenhancer of activated B cells (NF- $\kappa \mathrm{B}$ ) activation and production of pro-inflammatory cytokines. Termination of neutrophilic inflammation, essential to limit excessive tissue damage, is an active process regulated by several anti-inflammatory pathways that include neutrophil apoptosis and clearance and suppression of cytokine/chemokine responses. Although the immediate effect of NOX2 activation - generation of ROI and activation of proteases - is expected to increase tissue injury, NOX2 activation can also limit inflammation and injury.

The pathway through which neutrophils die probably affects their clearance and crosssignalling to circulating monocytes and macrophages. Apoptosis is the default mode of neutrophil death and occurs spontaneously at sites of inflammation [54]. In addition, macrophages release death receptor ligands [e.g. tumor necrosis factor- $a(\mathrm{TNF}-a)$ and Fas ligand], which can induce neutrophil apoptosis [55-57]. Macrophages recognize and ingest apoptotic neutrophils [54], a process known as efferocytosis. To stimulate efferocytosis, phosphatidylserine products are externalized by neutrophils early during apoptosis [58,59]. In contrast, NETotic neutrophils display phosphatidylserine only after plasma membrane rupture [39]. Moreover, release of primary neutrophil granular proteins can recruit circulating monocytes to the site of inflammation, stimulate macrophages to produce cytokines, and enhance the ability of macrophages to phagocytose bacteria [60-62]. Efferocytosis of neutrophils triggers the 'alternative activation' or the M2 phenotype of macrophages associated with IL-4 production and resolution of inflammation and repair of injury [63]. Efferocytosis can lead to anti-inflammatory responses, including production of prostaglandin $\mathrm{E}_{2}\left(\mathrm{PGE}_{2}\right)$, IL-10 and transforming growth factor- $\beta$ (TGF- $\beta$ ) by macrophages 
and suppression of the IL-23/IL-17A axis (IL-23 drives the expansion of Th17 cells), that drive neutrophil recruitment [64].

NOX2 in macrophages and neutrophils probably plays an important role in the cross-talk between these cells that promote neutrophil apoptosis and clearance. Accelerating neutrophil death and clearance are likely to be important modes by whichNOX2 limits acute inflammation. NOX2 in neutrophils can stimulate neutrophil death in specific settings. NOX2 stimulates neutrophil apoptosis after phagocytosis of opsonized particles [65]. TNF- $a$ and Fas ligand can both induce apoptosis in neutrophils, but through distinct signalling pathways; NOX2 was required for TNF- $a$-stimulated, but not Fas ligand-stimulated, apoptosis [56,66-68]. Thus, NOX2 can, in certain inflammatory contexts, promote apoptosis (non-inflammatory)whereas in other contexts promote NETosis (pro-inflammatory and injurious). Potentially, the intensity or kinetics of ROI generation or signalling pathways induced by specific mediators modulates the balance between apoptosis compared with NETosis.

Impaired neutrophil apoptosis may also contribute to persistent neutrophil inflammation in CGD. Coxon et al. [65] showed that phagocytosis-induced apoptosis was blocked both in neutrophils treated with the NOX2 inhibitor, DPI, and in neutrophils from CGD patients. Neutrophils from CGD patients are more resistant to spontaneous apoptosis in vitro than normal neutrophils and produce less prostaglandin $\mathrm{D}_{2}\left(\mathrm{PGD}_{2}\right)$ [69], an inflammatory mediator with both pro-allergic and anti-inflammatory properties. CGD macrophages are also impaired in both $\mathrm{PGD}_{2}$ and TGF- $\beta$ production during phagocytosis of apoptotic targets [69]. Thus, impaired neutrophil apoptosis and increased recruitment may together lead to dysregulated inflammation in CGD.

NOX2 in macrophages may have an important cross-signalling role in limiting neutrophilic inflammation. NOX2-deficient mice developed exuberant neutrophilic lung inflammation and pro-inflammatory cytokine responses to zymosan (fungal cell wall-derived particulate $\beta$ glucans), whereas inflammation in transgenic mice with NOX2 reconstituted in the monocyte/macrophage and dendritic cell lineage was self-limited and similar to wild-type mice [22]. NOX2 activation in macrophages can stimulate recognition and removal of apoptotic neutrophils [58,59,63,70]. Fernandez-Boyanapalli et al. [71] showed that impaired efferocytosis in CGD macrophages was associated with defective expression and activation of peroxisome proliferator activated receptor (PPAR) $-\gamma$, and that a PPAR- $\gamma$ agonist limited zymosan-induced peritonitis in CGD mice. Zeng et al. [72] showed that NOX2 was required for efferocytosis-induced IL-4 production and activation of IL-4-producing invariant natural killer T (iNKT) cells by macrophages. These results point to NOX2-regulated cross-talk between neutrophils and macrophages leading to death and clearance of neutrophils, required for resolution of inflammation and tissue repair.

NOX2 can also modulate acute inflammation and injury by regulation of transcriptional factors. When challenged with either intratracheal zymosan (particulate $\beta$-glucan that activates toll-like receptor 2 and Dectin-1) or lipopolysaccharide, NOX2-deficient $\mathrm{p} 47^{\text {phox }-/}$ mice and gp91 ${ }^{\text {phox }-/}$ mice developed exaggerated and progressive lung inflammation, augmented NF- $\kappa$ B activation and elevated downstream pro-inflammatory 
cytokines [TNF- $a$, IL-17A and granulocyte-colony stimulating factor (G-CSF)] compared with wild-type mice [73]. Replacement of functional NOX2 in bone marrow-derived cells restored the normal lung inflammatory response. Studies in vivo and in isolated macrophages demonstrated that NOX2 was required to activate nuclear factor erythroid 2related factor 2 (Nrf2), a ROI-inducible transcriptional factor that induces anti-inflammatory and cytoprotective responses. Consistent with these findings, zymosan-treated PBMCs from $\mathrm{X}$-linked CGD patients showed impaired Nrf2 activity and increased NF- $\kappa \mathrm{B}$ activation. Additional studies show that NOX2 regulates NF- $x$ B activation in macrophages by modulation of the intracellular redox status [74]. In addition to regulating inflammation in response to microbial constituents, NOX2 can limit inflammation in response to tissue injury. NOX2 was protective in acute acid aspiration-induced acute lung injury, limiting alveolar neutrophilic inflammation, inducing Nrf2 activation in lungs and reducing alveolarcapillary wall leak $[75,76]$.

These results show that NOX2 can limit lung inflammation and injury in response to pathogens, microbial products and direct tissue injury. Since the current understanding is that ROIs are proinflammatory and injurious, an anti-inflammatory effect ofNOX 2 - the major source of ROI generation in activated phagocytes - is paradoxical. However, through its modulation of multiple pathways involved in inflammation and injury, NOX2 can serve to resolve inflammation and limit tissue injury.

\section{NOX2 REGULATES ADAPTIVE IMMUNITY}

NOX2 can modulate adaptive immunity at multiple levels, including antigen presentation and cross-signalling to T- and B-cells. NOX2 is expressed in dendritic cells and recruited to early phagosomes, leading to sustained production of low levels of ROI and alkalinization of the phagosomal lumen [77,78]. The recruitment of NOX2 can prevent acidification of phagosomes, limiting antigen degradation and enhancing antigen presentation, including antigen cross-presentation $[6,78,79]$. Rab27a regulates NOX2 recruitment to dendritic cell phagosomes and phagosomal $\mathrm{pH}$ [79]. Cross-priming of $\mathrm{CD}^{+}{ }^{+}$T-cells failed to occur inNOX2-deficient mice due to defective endosomal alkalinization and autophagy in dendritic cells. However, vaccination of mice with fungal antigens that activated CD4 ${ }^{+} \mathrm{T}$ cells overcame defective cross-presentation, and was protective against Aspergillus challenge [80]. Dectin-1 signalling inmacrophages and dendritic cells triggers recruitment of light chain 3 (LC3) (a major component of the autophagy pathway) to phagosomes through pathways requiring activation of Syk, NOX2 and autophagy protein 5 (ATG5) $[81,82]$. This process facilitates recruitment of major histocompatibility complex (MHC) class II to phagosomes and promotes presentation of fungal antigens to $\mathrm{CD}^{+}{ }^{+} \mathrm{T}$-cells [82]. In additional to myeloid cells, NOX2 also regulates MHC-II expression on B-cells [83]. Together, these results point to a broad role for NOX2 in antigen presentation in multiple cell types [84], and the potential for vaccination targeted to $\mathrm{CD}^{+}$T-cell activation to ameliorate impaired host defence in CGD.

In addition to antigen presentation, NOX2 in myeloid cells can modulate T-cell phenotypes. IL-17A stimulates neutrophilic inflammation by inducing the expression of growth factors and pro-inflammatory cytokines and chemokines. Regulatory T-cells (Tregs; 
$\mathrm{CD} 4^{+} \mathrm{CD} 25^{+} \mathrm{Foxp}^{+}$) play an essential role in protection against autoimmunity by suppressing T-cell responses. Romani et al. [85] found that defective tryptophan catabolism led to impaired antifungal host defence and was associated with augmented Th17 and reduced Treg responses in NOX2-deficient mice. However, patients with CGD had normal tryptophan metabolism $[86,87]$. This difference between species may reflect the fact that superoxide anion is a cofactor for mouse, but not human, indoleamine 2,3-dioxygenase (IDO; which mediates tryptophan oxidation). Additional studies in mice also point to NOX2 in macrophages inducing Tregs and limiting autoimmune responses [23,88]. NOX2-deficient dendritic cells induced responding T-cells to produce higher levels of IFN- $\gamma$ and IL-17 after antigen-specific or superantigen-induced activation compared with wild-type dendritic cells [89].

Cross-signalling between myeloid cell-derived ROIs and T-cells is not well understood. Tcell surface oxidative stress has been posited to limit T-cell reactivity and sensitivity to autoimmunity $[90,91]$. However, another potential way NOX2 in myeloid cells can regulate adaptive immunity is by priming the development of myeloid-derived suppressor cells (MDSC). MDSC are immature myeloid cells that are expanded during cancer, sepsis [92,93] and other diseases associated with systemic inflammation. NOX2 has been shown to increase MDSC accumulation in various tumour-bearing mouse models [94,95], and the immunosuppressive capacity of monocytic MDSC in patients with non-small cell lung cancer was ROI-dependent [96]. Granulocytic MDSC have a functional NOX2; however in a mouse model of ovarian cancer, accumulation of MDSCs was not dependent on NOX2 [97]. By definition, MDSC suppress T-cell responses, which may serve to protect the host from excessive inflammation and autoimmunity. However, in the context of cancer, MDSC accumulation can disable T-cell-driven anti-cancer immunity. Although more research is required, these results suggest thatNOX2 stimulation of MDSC may be a mode for dampening immune response to avoid injury and autoimmunity, and in the tumour microenvironment may be a target to enhance anti-tumour immunity.

\section{NOX2 CALIBRATES THE INFLAMMATORY RESPONSE TO FUNGI}

NOX2 has a dual function; it is essential for antibacterial and antifungal host defence and it regulates both acute neutrophilic responses and adaptive immunity. One of the clearest findings showing a role for NOX2 in limiting fungal inflammation distinct from its host defence function is that NOX2-deficient mice developed excessive and prolonged lung inflammation compared with wild-type mice following intrapulmonary challenge with heatkilled $A$. fumigatus hyphae [98]. Since this study, significant knowledge has been gained about the molecular mechanisms for NOX2 modulating both antifungal host defence and inflammation.

Fungal motifs, including cell wall constituents and DNA, ligate specific PRR. Dectin-1 is the receptor and immunomodulator of particulate $\beta$-glucans (ubiquitous cell wall products of fungi and plants) $[99,100]$. Dectin-1 is expressed on multiple myeloid cells, including monocyte/macrophages, neutrophils and dendritic cells [101]. Dectin-1 signals through the tyrosine kinase Syk and the caspase recruitment domain 9 (CARD9), leading to activation of 
NOX2 and NF- $x$ B-dependent production of IL-17A and other pro-inflammatory cytokine and chemokines that recruit neutrophils [102-105].

Although the specific roles of Dectin-1 in myeloid cell populations has not been fully elucidated, we can speculate that the major effect in neutrophils is to activateNOX2dependent killing, whereas the major effect in dendritic cells is to prime Th17 responses. In alveolar macrophages, which are the first-line phagocytes that sense inhaled pathogens and microbial motifs, it is likely that the Dectin-1/NOX2 axis plays a dual role in limiting the growth of phagocytosed spores while also calibrating downstream inflammatory responses. A. fumigatus spores are coated with a hydrophobic protein that masks pro-inflammatory cell wall products [106]. During germination, which is the developmental transition from spores to hyphae, the cell wall $\beta$-glucans become unmasked and able to bind to Dectin-1, which now leads toNOX2 activation and production of pro-inflammatory signals [107-109] (Figure 2). Macrophage Dectin- 1 is activated by particulate rather than soluble $\beta$-glucans, which is proposed as a mechanism to distinguish cell wall-associated $\beta$-glucans associated with live fungi from those that are soluble (probably a fungal degradation product) [110]. The ability of host, lung resident cells to recognize the fungal cell wall products in a manner that is specific to stages of fungal development and, consequently, pathogenic ability probably enables the host to respond to the tissue-invasive forms (germlings and hyphae) while avoiding inflammation to commonly inhaled spores or soluble fungal cell wall products that do not constitute a threat.

Acute neutrophilic inflammation is an emergency response to infectious threat (or to microbial constituents or products of cellular necrosis that mimic infection). In Dectin-1deficient mice, production of IL-17A and other pro-inflammatory cytokines and chemokines and neutrophilic inflammation in response to Aspergillus infection are blunted. A modest impairment in host defence to Aspergillus is also observed, although not as severe as in NOX2-deficient mice [103]. Once neutrophils are engaged, NOX2 is critical for host defence against hyphae. As previously discussed, neutrophil NOX2 can damage hyphae both through a direct effect of ROI generated by the NOX2-MPO pathway, and also amplified by NET generation. It is unclear what the relative requirements for direct ROI injury compared with NET generation are in targeting hyphae during pulmonary Aspergillus infection since NOX2 activation promotes NETs. Finally, based largely on murine models, NOX2 probably also limits neutrophilic inflammation by dampening Th17 responses.

\section{NADPH OXIDASE PROTECTS AGAINST INFLAMMATORY BOWEL DISEASE}

IBD is thought to result from disordered host-microbe interactions in the bowel [111]. IBD resembling Crohn's disease occurs in about one-third of CGD patients [8,15,112]. Moreover, IBD observed in patients with very early onset IBD (VEOIBD; defined as onset of disease at younger than 6 years of age) often resembles features of CGD. Functional genetic variants in NOX2 components, although not severe enough to results in CGD, have been associated with VEOIBD [113,114]. Muise et al. [115] identified a polymorphism in $\mathrm{p}^{\text {phox }}$ gene that led to reduced binding of the protein to RAC2 in a subset of patients with VEOIBD. Mutations in the $\mathrm{p} 40^{\text {phox }}$ gene have also been linked to risk of Crohn's disease [115-118]. 
These studies suggest shared signalling pathways between NOX2 and pathways that protect from IBD.

Genetic studies have linked IBD to a large number of pathways that shape immune responses, including activation of autophagy, PRR (e.g. NOD2/CARD15, and toll-like receptor 4), cytokines and their receptors and various signalling pathways (e.g. signal transducer and activator of transcription 3 (STAT3) and CARD9). IBD has also been observed in a number of primary immunodeficiencies, such as the Wiskott-Aldrich syndrome and IPEX (immunodysregulation, polyendocrinopathy, enteropathy, X-linked syndrome), and CGD. These observations raise the question as to whether in patients with primary immune disorders, IBD is primarily the result of disordered inflammation or defective host defence leading to impaired clearance of microbes, pro-inflammatory microbial products and potentially food antigens [119].

NOX2 can affect numerous pathways relevant to IBD, including neutrophilic accumulation, transcriptional factor activation, cytokine responses, processing and clearance of microbial products and antigens, and adaptive immunity. NOX2 deficiency may lead to augmented IL-17A and attenuated Treg responses that, at least in part, account for the extraordinarily high frequency of IBD in CGD. The balance between the IL-23/IL-17A axis and Tregs is likely to be important in responding to intestinal microbial infections while limiting autoimmunity. The importance of Tregs in limiting autoimmunity is demonstrated in IPEX, which results from mutations in the Foxp3 gene, and characterized by a lack of Treg cells, leading to lymphoproliferation, and multiple autoimmune diseases including IBD. IL-23 and IL-17 are the major mediators of experimental IBD [120,121], whereas Tregs have a protective role [122]. Increased IL-17 and IL-23 expression has been associated with IBD in patients [121,123], and polymorphisms in the IL-23R gene are highly correlated with risk of Crohn's disease [124-127].

Rivas et al. [128] identified a highly significant association between a splice variant of CARD9 and protection from IBD. Since activation of Dectin-1 can result in CARD9dependent production of IL-17A and other pro-inflammatory cytokines, this observation raises the notion that immune responses to $\beta$-glucan (e.g. from Candida species colonizing the bowel or foods containing $\beta$-glucan) in bowel mucosa may influence the risk for IBD. Iliev et al. [129] demonstrated that mice lacking Dectin-1 had altered responses to indigenous fungi (referred to as the 'mycobiome') and more severe chemically-induced colitis. In addition, a polymorphism in CLEC7A, the gene encoding Dectin-1, was linked to a more severe form of ulcerative colitis. Seen in this light, NOX2, which is also activated by Dectin-1 ligation, might dampen IL-17A responses and protect from IBD.

de Luca et al. [130] recently linked defective autophagy (associated with impaired phagosomal recruitment of LC3) in CGD to increased IL-1 $\beta$-driven inflammation. The IL-1 receptor antagonist, anakinra, restored autophagy in CGD mice. Moreover, anakinra decreased neutrophil recruitment and Th17 responses in CGD mice, and was protective in models of colitis and aspergillosis. These findings show a new mechanism for hyperinflammation in CGD and point to IL-1 blockade as a potential therapeutic approach. 


\section{CONCLUSION}

CGD is a rare inherited disorder of the phagocyte NOX2 from which we can learn about the function of this enzyme, both as a mediator of host defence and of inflammation. From CGD patients and CGD mouse models, we have learned that NOX2, in addition to defending against a spectrum of bacterial and fungal pathogens, also limits neutrophilic inflammation through several mechanisms. Effective calibration of neutrophilic inflammation is critical in protecting the host from infection, while averting injury associated with excessive or persistent inflammation. Knowledge gained about mechanisms by which NOX2 and its downstream pathways modulate host defence and inflammation may lead to novel therapeutic targets both for CGD patients, and, more broadly, for diseases associated with excessive inflammation (e.g. autoimmunity) and inflammation-induced organ injury.

\section{Acknowledgments}

FUNDING

This work was supported by the National Institutes of Health [grant numbers R01 AI79253 and T32 CA085183 (to B.H.S. and K.P.L.)].

\section{Abbreviations}

$\begin{array}{ll}\text { ATG5 } & \text { autophagy protein 5 } \\ \text { BALF } & \text { bronchoalveolar lavage fluid } \\ \text { CARD } & \text { caspase recruitment domain } \\ \text { CGD } & \text { chronic granulomatous disease } \\ \text { DAMPs } & \text { damage-associated molecular patterns } \\ \text { DUOX } & \text { dual oxidase } \\ \text { G-CSF } & \text { granulocyte-colony stimulating factor } \\ \text { IBD } & \text { inflammatory bowel disease } \\ \text { IDO } & \text { indoleamine 2,3-dioxygenase } \\ \text { IFN- } \gamma & \text { interferon- } \gamma \\ \text { IL } & \text { interleukin } \\ \text { iNKT } & \text { invariant natural killer T cell } \\ \text { LC3 } & \text { light chain } 3 \\ \text { MDSC } & \text { myeloid-derived suppressor cell } \\ \text { MPO } & \text { major histocompatibility complex } \\ \text { MHC } & \text { myeloperoxidase } \\ \text { MA } & \end{array}$




\begin{tabular}{ll} 
NET & neutrophil extracellular trap \\
NF- $\boldsymbol{x B}$ & nuclear factor kappa-light-chain-enhancer of activated B cells \\
NOD & nucleotide-oligomerization domain \\
Nrf2 & nuclear factor erythroid 2-related factor 2 \\
OLFM4 & olfactomedin 4 \\
PBMC & peripheral blood mononuclear cell \\
PGD & prostaglandin $\mathrm{D}_{2}$ \\
PPAR & peroxisome proliferator-activated receptor \\
PRR & pathogen recognition receptors \\
ROI & reactive oxidant intermediates \\
STAT3 & signal transducer and activator of transcription 3 \\
Syk & spleen tyrosine kinase \\
TGF- $\beta$ & transforming growth factor- $\beta$ \\
TNF- $\boldsymbol{a}$ & tumor necrosis factor- $\boldsymbol{\alpha}$ \\
Treg & regulatory T-cell \\
VEOIBD & very early onset IBD \\
\hline
\end{tabular}

\section{References}

1. Ha EM, Oh CT, Bae YS, Lee WJ. A direct role for dual oxidase in Drosophila gut immunity. Science. 2005; 310:847-850. [PubMed: 16272120]

2. Ha EM, Lee KA, Park SH, Kim SH, Nam HJ, Lee HY, Kang D, Lee WJ. Regulation of DUOX by the Galphaq-phospholipase Cbeta-Ca ${ }^{2+}$ pathway in Drosophila gut immunity. Dev Cell. 2009; 16:386-397. [PubMed: 19289084]

3. Bedard K, Lardy B, Krause KH. NOX family NADPH oxidases: not just in mammals. Biochimie. 2007; 89:1107-1112. [PubMed: 17400358]

4. Segal AW, Garcia R, Goldstone H, Cross AR, Jones OT. Cytochrome b-245 of neutrophils is also present in human monocytes, macrophages and eosinophils. Biochem J. 1981; 196:363-367. [PubMed: 7306076]

5. Elsen S, Doussiere J, Villiers CL, Faure M, Berthier R, Papaioannou A, Grandvaux N, Marche PN, Vignais PV. Cryptic O2 ${ }^{-}$-generating NADPH oxidase in dendritic cells. J Cell Sci. 2004; 117(Pt 11):2215-2226. [PubMed: 15126623]

6. Graham DB, Stephenson LM, Lam SK, Brim K, Lee HM, Bautista J, Gilfillan S, Akilesh S, Fujikawa K, Swat W. An ITAM-signaling pathway controls cross-presentation of particulate but not soluble antigens in dendritic cells. J Exp Med. 2007; 204:2889-2897. [PubMed: 17984307]

7. Leto TL, Geiszt M. Role of Nox family NADPH oxidases in host defense. Antioxid Redox Signal. 2006; 8(9-10):1549-1561. [PubMed: 16987010]

8. Segal BH, Veys P, Malech H, Cowan MJ. Chronic granulomatous disease: lessons from a rare disorder. Biol Blood Marrow Transplant. 2011; 17(1 Suppl):S123-S131. [PubMed: 21195301] 
9. Kuhns DB, Alvord WG, Heller T, Feld JJ, Pike KM, Marciano BE, Uzel G, DeRavin SS, Priel DA, Soule BP, et al. Residual NADPH oxidase and survival in chronic granulomatous disease. N Engl J Med. 2010; 363:2600-2610. [PubMed: 21190454]

10. Mocsai A, Zhou M, Meng F, Tybulewicz VL, Lowell CA. Syk is required for integrin signaling in neutrophils. Immunity. 2002; 16:547-558. [PubMed: 11970878]

11. Gantner BN, Simmons RM, Canavera SJ, Akira S, Underhill DM. Collaborative induction of inflammatory responses by dectin-1 and Toll-like receptor 2. J Exp Med. 2003; 197:1107-1117. [PubMed: 12719479]

12. Harrison JE, Schultz J. Studies on the chlorinating activity of myeloperoxidase. J Biol Chem. 1976; 251:1371-1374. [PubMed: 176150]

13. Albrich JM, McCarthy CA, Hurst JK. Biological reactivity of hypochlorous acid: implications for microbicidal mechanisms of leukocyte myeloperoxidase. Proc Natl Acad Sci USA. 1981; 78:210 214. [PubMed: 6264434]

14. Weiss SJ, Klein R, Slivka A, Wei M. Chlorination of taurine by human neutrophils. Evidence for hypochlorous acid generation. J Clin Invest. 1982; 70:598-607. [PubMed: 6286728]

15. Marciano BE, Rosenzweig SD, Kleiner DE, Anderson VL, Darnell DN, Anaya-O'Brien S, Hilligoss DM, Malech HL, Gallin JI, Holland SM. Gastrointestinal involvement in chronic granulomatous disease. Pediatrics. 2004; 114:462-468. [PubMed: 15286231]

16. De Ravin SS, Naumann N, Robinson MR, Barron KS, Kleiner DE, Ulrick J, Friend J, Anderson VL, Darnell D, Kang EM, et al. Sarcoidosis in chronic granulomatous disease. Pediatrics. 2006; 117:e590-e595. [PubMed: 16452321]

17. Segal BH, Grimm MJ, Khan AN, Han W, Blackwell TS. Regulation of innate immunity by NADPH oxidase. Free Radic Biol Med. 2012; 53:72-80. [PubMed: 22583699]

18. Bustamante J, Arias AA, Vogt G, Picard C, Galicia LB, Prando C, Grant AV, Marchal CC, Hubeau M, Chapgier A, et al. Germline CYBB mutations that selectively affect macrophages in kindreds with X-linked predisposition to tuberculous mycobacterial disease. Nat Immunol. 2011; 12:213221. [PubMed: 21278736]

19. Schaffner A, Douglas H, Braude A. Selective protection against conidia by mononuclear and against mycelia by polymorphonuclear phagocytes in resistance to Aspergillus. Observations on these two lines of defense in vivo and in vitro with human and mouse phagocytes. J Clin Invest. 1982; 69:617-631. [PubMed: 7037853]

20. Philippe B, Ibrahim-Granet O, Prevost MC, Gougerot-Pocidalo MA, Sanchez Perez M, Van der Meeren A, Latge JP. Killing of Aspergillus fumigatus by alveolar macrophages is mediated by reactive oxidant intermediates. Infect Immun. 2003; 71:3034-3042. [PubMed: 12761080]

21. Cornish EJ, Hurtgen BJ, McInnerney K, Burritt NL, Taylor RM, Jarvis JN, Wang SY, Burritt JB. Reduced nicotinamide adenine dinucleotide phosphate oxidase-independent resistance to Aspergillus fumigatus in alveolar macrophages. J Immunol. 2008; 180:6854-6867. [PubMed: 18453606]

22. Grimm MJ, Vethanayagam RR, Almyroudis NG, Dennis CG, Khan AN, D’Auria AC, Singel KL, Davidson BA, Knight PR, Blackwell TS, et al. Monocyte- and macrophage-targeted NADPH oxidase mediates antifungal host defense and regulation of acute inflammation in mice. $\mathrm{J}$ Immunol. 2013; 190:4175-4184. [PubMed: 23509361]

23. Gelderman KA, Hultqvist M, Pizzolla A, Zhao M, Nandakumar KS, Mattsson R, Holmdahl R. Macrophages suppress $\mathrm{T}$ cell responses and arthritis development in mice by producing reactive oxygen species. J Clin Invest. 2007; 117:3020-3028. [PubMed: 17909630]

24. Pizzolla A, Hultqvist M, Nilson B, Grimm MJ, Eneljung T, Jonsson IM, Verdrengh M, Kelkka T, Gjertsson I, Segal BH, et al. Reactive oxygen species produced by the NADPH oxidase 2 complex in monocytes protect mice from bacterial infections. J Immunol. 2012; 188:5003-5011. [PubMed: 22491245]

25. Graham DB, Robertson CM, Bautista J, Mascarenhas F, Diacovo MJ, Montgrain V, Lam SK, Cremasco V, Dunne WM, Faccio R, et al. Neutrophil-mediated oxidative burst and host defense are controlled by a Vav-PLCgamma2 signaling axis in mice. J Clin Invest. 2007; 117:3445-3452. [PubMed: 17932569] 
26. Van Ziffle JA, Lowell CA. Neutrophil-specific deletion of Syk kinase results in reduced host defense to bacterial infection. Blood. 2009; 114:4871-4882. [PubMed: 19797524]

27. Winkelstein JA, Marino MC, Johnston RB Jr, Boyle J, Curnutte J, Gallin JI, Malech HL, Holland SM, Ochs H, Quie P, et al. Chronic granulomatous disease. Report on a national registry of 368 patients. Medicine. 2000; 79:155-169. [PubMed: 10844935]

28. van den Berg JM, van Koppen E, Ahlin A, Belohradsky BH, Bernatowska E, Corbeel L, Espanol T, Fischer A, Kurenko-Deptuch M, Mouy R, et al. Chronic granulomatous disease: the European experience. PLoS One. 2009; 4:e5234. [PubMed: 19381301]

29. Zarember KA, Sugui JA, Chang YC, Kwon-Chung KJ, Gallin JI. Human polymorphonuclear leukocytes inhibit Aspergillus fumigatus conidial growth by lactoferrin-mediated iron depletion. J Immunol. 2007; 178:6367-6373. [PubMed: 17475866]

30. Henriet SS, Hermans PW, Verweij PE, Simonetti E, Holland SM, Sugui JA, Kwon-Chung KJ, Warris A. Human leukocytes kill Aspergillus nidulans by reactive oxygen species-independent mechanisms. Infect Immun. 2011; 79:767-773. [PubMed: 21078850]

31. Segal BH, DeCarlo ES, Kwon-Chung KJ, Malech HL, Gallin JI, Holland SM. Aspergillus nidulans infection in chronic granulomatous disease. Medicine. 1998; 77:345-354. [PubMed: 9772923]

32. Liu W, Yan M, Sugui JA, Li H, Xu C, Joo J, Kwon-Chung KJ, Coleman WG, Rodgers GP. Olfm4 deletion enhances defense against Staphylococcus aureus in chronic granulomatous disease. J Clin Invest. 2013; 123:3751-3755. [PubMed: 23908114]

33. Segal AW, Geisow M, Garcia R, Harper A, Miller R. The respiratory burst of phagocytic cells is associated with a rise in vacuolar pH. Nature. 1981; 290:406-409. [PubMed: 7219526]

34. Reeves EP, Lu H, Jacobs HL, Messina CG, Bolsover S, Gabella G, Potma EO, Warley A, Roes J, Segal AW. Killing activity of neutrophils is mediated through activation of proteases by $\mathrm{K}+$ flux. Nature. 2002; 416:291-297. [PubMed: 11907569]

35. Henriet SS, Jans J, Simonetti E, Kwon-Chung KJ, Rijs AJ, Hermans PW, Holland SM, de Jonge MI, Warris A. Chloroquine modulates the fungal immune response in phagocytic cells from patients with chronic granulomatous disease. J Infect Dis. 2013; 207:1932-1939. [PubMed: 23482646]

36. Brinkmann V, Reichard U, Goosmann C, Fauler B, Uhlemann Y, Weiss DS, Weinrauch Y, Zychlinsky A. Neutrophil extracellular traps kill bacteria. Science. 2004; 303:1532-1535. [PubMed: 15001782]

37. Yipp BG, Petri B, Salina D, Jenne CN, Scott BN, Zbytnuik LD, Pittman K, Asaduzzaman M, Wu $\mathrm{K}$, Meijndert HC, et al. Infection-induced NETosis is a dynamic process involving neutrophil multitasking in vivo. Nat Med. 2012; 18:1386-1393. [PubMed: 22922410]

38. Caudrillier A, Kessenbrock K, Gilliss BM, Nguyen JX, Marques MB, Monestier M, Toy P, Werb Z, Looney MR. Platelets induce neutrophil extracellular traps in transfusion-related acute lung injury. J Clin Invest. 2012; 122:2661-2671. [PubMed: 22684106]

39. Fuchs TA, Abed U, Goosmann C, Hurwitz R, Schulze I, Wahn V, Weinrauch Y, Brinkmann V, Zychlinsky A. Novel cell death program leads to neutrophil extracellular traps. J Cell Biol. 2007; 176:231-241. [PubMed: 17210947]

40. Brinkmann V, Laube B, Abu Abed U, Goosmann C, Zychlinsky A. Neutrophil extracellular traps: how to generate and visualize them. J Vis Exp. 2010; 36:e1724.

41. Rohm M, Grimm MJ, D’Auria AC, Almyroudis NG, Segal BH, Urban CF. NADPH oxidase promotes neutrophil extracellular trap formation in pulmonary aspergillosis. Infect Immun. 2014; 82:1766-1777. [PubMed: 24549323]

42. Urban CF, Lourido S, Zychlinsky A. How do microbes evade neutrophil killing? Cell Microbiol. 2006; 8:1687-1696. [PubMed: 16939535]

43. Bianchi M, Hakkim A, Brinkmann V, Siler U, Seger RA, Zychlinsky A, Reichenbach J. Restoration of NET formation by gene therapy in CGD controls aspergillosis. Blood. 2009; 114:2619-2622. [PubMed: 19541821]

44. Metzler KD, Fuchs TA, Nauseef WM, Reumaux D, Roesler J, Schulze I, Wahn V, Papayannopoulos V, Zychlinsky A. Myeloperoxidase is required for neutrophil extracellular trap formation: implications for innate immunity. Blood. 2011; 117:953-959. [PubMed: 20974672] 
45. Urban CF, Ermert D, Schmid M, Abu-Abed U, Goosmann C, Nacken W, Brinkmann V, Jungblut PR, Zychlinsky A. Neutrophil extracellular traps contain calprotectin, a cytosolic protein complex involved in host defense against Candida albicans. PLoS Pathog. 2009; 5:e1000639. [PubMed: 19876394]

46. Bianchi M, Niemiec MJ, Siler U, Urban CF, Reichenbach J. Restoration of anti-Aspergillus defense by neutrophil extracellular traps in human chronic granulomatous disease after gene therapy is calprotectin-dependent. J Allergy Clin Immunol. 2011; 127:1243-1252. e7. [PubMed: 21376380]

47. Palmer LJ, Cooper PR, Ling MR, Wright HJ, Huissoon A, Chapple IL. Hypochlorous acid regulates neutrophil extracellular trap release in humans. Clin Exp Immunol. 2012; 167:261-268. [PubMed: 22236002]

48. Akong-Moore K, Chow OA, von Kockritz-Blickwede M, Nizet V. Influences of chloride and hypochlorite on neutrophil extracellular trap formation. PLoS One. 2012; 7:e42984. [PubMed: 22912772]

49. Yamada M, Gomez JC, Chugh PE, Lowell CA, Dinauer MC, Dittmer DP, Doerschuk CM. Interferon-gamma production by neutrophils during bacterial pneumonia in mice. Am J Respir Crit Care Med. 2011; 183:1391-1401. [PubMed: 21169470]

50. Pilsczek FH, Salina D, Poon KK, Fahey C, Yipp BG, Sibley CD, Robbins SM, Green FH, Surette MG, Sugai M, et al. A novel mechanism of rapid nuclear neutrophil extracellular trap formation in response to Staphylococcus aureus. J Immunol. 2010; 185:7413-7425. [PubMed: 21098229]

51. Farley K, Stolley JM, Zhao P, Cooley J, Remold-O'Donnell E. A serpinB1 regulatory mechanism is essential for restricting neutrophil extracellular trap generation. J Immunol. 2012; 189:45744581. [PubMed: 23002442]

52. Parker H, Dragunow M, Hampton MB, Kettle AJ, Winterbourn CC. Requirements for NADPH oxidase and myeloperoxidase in neutrophil extracellular trap formation differ depending on the stimulus. J Leukoc Biol. 2012; 92:841-849. [PubMed: 22802447]

53. Douda DN, Khan MA, Grasemann H, Palaniyar N. SK3 channel and mitochondrial ROS mediate NADPH oxidase-independent NETosis induced by calcium influx. Proc Natl Acad Sci USA. 2015; 112:2817-2822. [PubMed: 25730848]

54. Savill JS, Wyllie AH, Henson JE, Walport MJ, Henson PM, Haslett C. Macrophage phagocytosis of aging neutrophils in inflammation. Programmed cell death in the neutrophil leads to its recognition by macrophages. J Clin Invest. 1989; 83:865-875. [PubMed: 2921324]

55. Brown SB, Savill J. Phagocytosis triggers macrophage release of Fas ligand and induces apoptosis of bystander leukocytes. J Immunol. 1999; 162:480-485. [PubMed: 9886423]

56. Yamashita K, Takahashi A, Kobayashi S, Hirata H, Mesner PW Jr, Kaufmann SH, Yonehara S, Yamamoto K, Uchiyama T, Sasada M. Caspases mediate tumor necrosis factor-alpha-induced neutrophil apoptosis and downregulation of reactive oxygen production. Blood. 1999; 93:674-685. [PubMed: 9885230]

57. Renshaw SA, Timmons SJ, Eaton V, Usher LR, Akil M, Bingle CD, Whyte MK. Inflammatory neutrophils retain susceptibility to apoptosis mediated via the Fas death receptor. J Leukoc Biol. 2000; 67:662-668. [PubMed: 10811006]

58. Frasch SC, Berry KZ, Fernandez-Boyanapalli R, Jin HS, Leslie C, Henson PM, Murphy RC, Bratton DL. NADPH oxidase-dependent generation of lysophosphatidylserine enhances clearance of activated and dying neutrophils via G2A. J Biol Chem. 2008; 283:33736-33749. [PubMed: 18824544]

59. Frasch SC, Fernandez-Boyanapalli RF, Berry KZ, Leslie CC, Bonventre JV, Murphy RC, Henson PM, Bratton DL. Signaling via macrophage G2A enhances efferocytosis of dying neutrophils by augmentation of Rac activity. J Biol Chem. 2011; 286:12108-12122. [PubMed: 21297111]

60. Soehnlein O, Kai-Larsen Y, Frithiof R, Sorensen OE, Kenne E, Scharffetter-Kochanek K, Eriksson EE, Herwald H, Agerberth B, Lindbom L. Neutrophil primary granule proteins HBP and HNP1-3 boost bacterial phagocytosis by human and murine macrophages. J Clin Invest. 2008; 118:34913502. [PubMed: 18787642]

61. Soehnlein O, Weber C, Lindbom L. Neutrophil granule proteins tune monocytic cell function. Trends Immunol. 2009; 30:538-546. [PubMed: 19699683] 
62. Soehnlein O, Zernecke A, Weber C. Neutrophils launch monocyte extravasation by release of granule proteins. Thromb Haemost. 2009; 102:198-205. [PubMed: 19652869]

63. Fernandez-Boyanapalli RF, Frasch SC, McPhillips K, Vandivier RW, Harry BL, Riches DW, Henson PM, Bratton DL. Impaired apoptotic cell clearance in CGD due to altered macrophage programming is reversed by phosphatidylserine-dependent production of IL-4. Blood. 2009; 113:2047-2055. [PubMed: 18952895]

64. Stark MA, Huo Y, Burcin TL, Morris MA, Olson TS, Ley K. Phagocytosis of apoptotic neutrophils regulates granulopoiesis via IL-23 and IL-17. Immunity. 2005; 22:285-294. [PubMed: 15780986]

65. Coxon A, Rieu P, Barkalow FJ, Askari S, Sharpe AH, von Andrian UH, Arnaout MA, Mayadas TN. A novel role for the beta 2 integrin CD11b/CD18 in neutrophil apoptosis: a homeostatic mechanism in inflammation. Immunity. 1996; 5:653-666. [PubMed: 8986723]

66. Liles WC, Kiener PA, Ledbetter JA, Aruffo A, Klebanoff SJ. Differential expression of Fas (CD95) and Fas ligand on normal human phagocytes: implications for the regulation of apoptosis in neutrophils. J Exp Med. 1996; 184:429-440. [PubMed: 8760796]

67. van den Berg JM, Weyer S, Weening JJ, Roos D, Kuijpers TW. Divergent effects of tumor necrosis factor alpha on apoptosis of human neutrophils. J Leukoc Biol. 2001; 69:467-473. [PubMed: 11261795]

68. O’Donnell JA, Kennedy CL, Pellegrini M, Nowell CJ, Zhang JG, O'Reilly LA, Cengia L, Dias S, Masters SL, Hartland EL, et al. Fas regulates neutrophil lifespan during viral and bacterial infection. J Leukoc Biol. 2015; 97:321-326. [PubMed: 25473101]

69. Brown JR, Goldblatt D, Buddle J, Morton L, Thrasher AJ. Diminished production of antiinflammatory mediators during neutrophil apoptosis and macrophage phagocytosis in chronic granulomatous disease (CGD). J Leukoc Biol. 2003; 73:591-599. [PubMed: 12714573]

70. Sanmun D, Witasp E, Jitkaew S, Tyurina YY, Kagan VE, Ahlin A, Palmblad J, Fadeel B. Involvement of a functional NADPH oxidase in neutrophils and macrophages during programmed cell clearance: implications for chronic granulomatous disease. Am J Physiol Cell Physiol. 2009; 297:C621-C631. [PubMed: 19570889]

71. Fernandez-Boyanapalli R, Frasch SC, Riches DW, Vandivier RW, Henson PM, Bratton DL. PPARgamma activation normalizes resolution of acute sterile inflammation in murine chronic granulomatous disease. Blood. 2010; 116:4512-4522. [PubMed: 20693431]

72. Zeng MY, Pham D, Bagaitkar J, Liu J, Otero K, Shan M, Wynn TA, Brombacher F, Brutkiewicz RR, Kaplan MH, et al. An efferocytosis-induced, IL-4-dependent macrophage-iNKT cell circuit suppresses sterile inflammation and is defective in murine CGD. Blood. 2013; 121:3473-3483. [PubMed: 23426944]

73. Segal BH, Han W, Bushey JJ, Joo M, Bhatti Z, Feminella J, Dennis CG, Vethanayagam RR, Yull FE, Capitano M, et al. NADPH oxidase limits innate immune responses in the lungs in mice. PLoS One. 2010; 5:e9631. [PubMed: 20300512]

74. Han W, Li H, Cai J, Gleaves LA, Polosukhin VV, Segal BH, Yull FE, Blackwell TS. NADPH oxidase limits lipopolysaccharide-induced lung inflammation and injury in mice through redox regulation of NF-kB activity. J Immunol. 2013; 190:4786-4794. [PubMed: 23530143]

75. Davidson BA, Vethanayagam RR, Grimm MJ, Mullan BA, Raghavendran K, Blackwell TS, Freeman ML, Ayyasamy V, Singh KK, Sporn MB, et al. NADPH oxidase and Nrf2 regulate gastric aspiration-induced inflammation and acute lung injury. J Immunol. 2013; 190:1714-1724. [PubMed: 23296708]

76. Segal BH, Davidson BA, Hutson AD, Russo TA, Holm BA, Mullan B, Habitzruther M, Holland SM, Knight PR 3rd. Acid aspiration-induced lung inflammation and injury are exacerbated in NADPH oxidase-deficient mice. Am J Physiol Lung Cell Mol Physiol. 2007; 292:L760-L768. [PubMed: 17114280]

77. Savina A, Jancic C, Hugues S, Guermonprez P, Vargas P, Moura IC, Lennon-Dumenil AM, Seabra $\mathrm{MC}$, Raposo G, Amigorena S. NOX2 controls phagosomal $\mathrm{pH}$ to regulate antigen processing during crosspresentation by dendritic cells. Cell. 2006; 126:205-218. [PubMed: 16839887]

78. Mantegazza AR, Savina A, Vermeulen M, Perez L, Geffner J, Hermine O, Rosenzweig SD, Faure $\mathrm{F}$, Amigorena S. NADPH oxidase controls phagosomal $\mathrm{pH}$ and antigen cross-presentation in human dendritic cells. Blood. 2008; 112:4712-4722. [PubMed: 18682599] 
79. Jancic C, Savina A, Wasmeier C, Tolmachova T, El-Benna J, Dang PM, Pascolo S, GougerotPocidalo MA, Raposo G, Seabra MC, et al. Rab27a regulates phagosomal pH and NADPH oxidase recruitment to dendritic cell phagosomes. Nat Cell Biol. 2007; 9:367-378. [PubMed: 17351642]

80. Luca AD, Iannitti RG, Bozza S, Beau R, Casagrande A, D’Angelo C, Moretti S, Cunha C, Giovannini G, Massi-Benedetti C, et al. CD4+ T cell vaccination overcomes defective crosspresentation of fungal antigens in a mouse model of chronic granulomatous disease. J Clin Invest. 2012; 122:1816-1831. [PubMed: 22523066]

81. Tam JM, Mansour MK, Khan NS, Seward M, Puranam S, Tanne A, Sokolovska A, Becker CE, Acharya M, Baird MA, et al. Dectin-1 dependent LC3 recruitment to phagosomes enhances fungicidal activity in macrophages. J Infect Dis. 2014; 210:1844-1854. [PubMed: 24842831]

82. Ma J, Becker C, Lowell CA, Underhill DM. Dectin-1-triggered recruitment of light chain 3 protein to phagosomes facilitates major histocompatibility complex class II presentation of fungal-derived antigens. J Biol Chem. 2012; 287:34149-34156. [PubMed: 22902620]

83. Crotzer VL, Matute JD, Arias AA, Zhao H, Quilliam LA, Dinauer MC, Blum JS. Cutting edge: NADPH oxidase modulates MHC class II antigen presentation by B cells. J Immunol. 2012; 189:3800-3804. [PubMed: 22984083]

84. Gardiner GJ, Deffit SN, McLetchie S, Perez L, Walline CC, Blum JS. A role for NADPH oxidase in antigen presentation. Front Immunol. 2013; 4:295. [PubMed: 24069023]

85. Romani L, Fallarino F, De Luca A, Montagnoli C, D’Angelo C, Zelante T, Vacca C, Bistoni F, Fioretti MC, Grohmann U, et al. Defective tryptophan catabolism underlies inflammation in mouse chronic granulomatous disease. Nature. 2008; 451:211-215. [PubMed: 18185592]

86. De Ravin SS, Zarember KA, Long-Priel D, Chan KC, Fox SD, Gallin JI, Kuhns DB, Malech HL. Tryptophan/kynurenine metabolism in human leukocytes is independent of superoxide and is fully maintained in chronic granulomatous disease. Blood. 2010; 116:1755-1760. [PubMed: 20511543]

87. Jurgens B, Fuchs D, Reichenbach J, Heitger A. Intact indoleamine 2,3-dioxygenase activity in human chronic granulomatous disease. Clin Immunol. 2010; 137:1-4. [PubMed: 20570568]

88. Kraaij MD, Savage ND, van der Kooij SW, Koekkoek K, Wang J, van den Berg JM, Ottenhoff TH, Kuijpers TW, Holmdahl R, van Kooten C, et al. Induction of regulatory T cells by macrophages is dependent on production of reactive oxygen species. Proc Natl Acad Sci USA. 2010; 107:1768617691. [PubMed: 20861446]

89. George-Chandy A, Nordstrom I, Nygren E, Jonsson IM, Postigo J, Collins LV, Eriksson K. Th17 development and autoimmune arthritis in the absence of reactive oxygen species. Eur J Immunol. 2008; 38:1118-1126. [PubMed: 18383034]

90. Gelderman KA, Hultqvist M, Holmberg J, Olofsson P, Holmdahl R. T cell surface redox levels determine T cell reactivity and arthritis susceptibility. Proc Natl Acad Sci USA. 2006; 103:1283112836. [PubMed: 16908843]

91. Holmdahl R, Sareila O, Pizzolla A, Winter S, Hagert C, Jaakkola N, Kelkka T, Olsson LM, Wing $\mathrm{K}$, Backdahl L. Hydrogen peroxide as an immunological transmitter regulating autoreactive $\mathrm{T}$ cells. Antioxid Redox Signal. 2012; 18:1463-1474. [PubMed: 22900704]

92. Darcy CJ, Minigo G, Piera KA, Davis JS, McNeil YR, Chen Y, Volkheimer AD, Weinberg JB, Anstey NM, Woodberry T. Neutrophils with myeloid derived suppressor function deplete arginine and constrain T cell function in septic shock patients. Crit Care. 2014; 18:R163. [PubMed: 25084831]

93. Janols H, Bergenfelz C, Allaoui R, Larsson AM, Ryden L, Bjornsson S, Janciauskiene S, Wullt M, Bredberg A, Leandersson K. A high frequency of MDSCs in sepsis patients, with the granulocytic subtype dominating in grampositive cases. J Leukoc Biol. 2014; 96:685-693. [PubMed: 24929004]

94. Cheng P, Corzo CA, Luetteke N, Yu B, Nagaraj S, Bui MM, Ortiz M, Nacken W, Sorg C, Vogl T, et al. Inhibition of dendritic cell differentiation and accumulation of myeloid-derived suppressor cells in cancer is regulated by S100A9 protein. J Exp Med. 2008; 205:2235-2249. [PubMed: 18809714]

95. Corzo CA, Cotter MJ, Cheng P, Cheng F, Kusmartsev S, Sotomayor E, Padhya T, McCaffrey TV, McCaffrey JC, Gabrilovich DI. Mechanism regulating reactive oxygen species in tumor-induced myeloid-derived suppressor cells. J Immunol. 2009; 182:5693-5701. [PubMed: 19380816] 
96. Huang A, Zhang B, Wang B, Zhang F, Fan KX, Guo YJ. Increased CD14(+)HLA-DR (-/low) myeloid-derived suppressor cells correlate with extrathoracic metastasis and poor response to chemotherapy in non-small cell lung cancer patients. Cancer Immunol Immunother. 2013; 62:1439-1451. [PubMed: 23760662]

97. Godoy HE, Khan AN, Vethanayagam RR, Grimm MJ, Singel KL, Kolomeyevskaya N, Sexton KJ, Parameswaran A, Abrams SI, Odunsi K, et al. Myeloid-derived suppressor cells modulate immune responses independently of NADPH oxidase in the ovarian tumor microenvironment in mice. PLoS One. 2013; 8:e69631. [PubMed: 23922763]

98. Morgenstern DE, Gifford MA, Li LL, Doerschuk CM, Dinauer MC. Absence of respiratory burst in X-linked chronic granulomatous disease mice leads to abnormalities in both host defense and inflammatory response to Aspergillus fumigatus. J Exp Med. 1997; 185:207-218. [PubMed: 9016870]

99. Brown GD, Gordon S. Immune recognition. A new receptor for beta-glucans. Nature. 2001; 413:36-37.

100. Netea MG, Gow NA, Munro CA, Bates S, Collins C, Ferwerda G, Hobson RP, Bertram G, Hughes HB, Jansen T, et al. Immune sensing of Candida albicans requires cooperative recognition of mannans and glucans by lectin and Toll-like receptors. J Clin Invest. 2006; 116:1642-1650. [PubMed: 16710478]

101. Taylor PR, Brown GD, Reid DM, Willment JA, Martinez-Pomares L, Gordon S, Wong SY. The beta-glucan receptor, dectin-1, is predominantly expressed on the surface of cells of the monocyte/macrophage and neutrophil lineages. J Immunol. 2002; 169:3876-3882. [PubMed: 12244185]

102. LeibundGut-Landmann S, Gross O, Robinson MJ, Osorio F, Slack EC, Tsoni SV, Schweighoffer E, Tybulewicz V, Brown GD, Ruland J, et al. Syk- and CARD9-dependent coupling of innate immunity to the induction of T helper cells that produce interleukin 17. Nat Immunol. 2007; 8:630-638. [PubMed: 17450144]

103. Werner JL, Metz AE, Horn D, Schoeb TR, Hewitt MM, Schwiebert LM, Faro-Trindade I, Brown GD, Steele C. Requisite role for the dectin-1 beta-glucan receptor in pulmonary defense against Aspergillus fumigatus. J Immunol. 2009; 182:4938-4946. [PubMed: 19342673]

104. Ferwerda B, Ferwerda G, Plantinga TS, Willment JA, van Spriel AB, Venselaar H, Elbers CC, Johnson MD, Cambi A, Huysamen C, et al. Human dectin-1 deficiency and mucocutaneous fungal infections. N Engl J Med. 2009; 361:1760-1767. [PubMed: 19864674]

105. Glocker EO, Hennigs A, Nabavi M, Schaffer AA, Woellner C, Salzer U, Pfeifer D, Veelken H, Warnatz K, Tahami F, et al. A homozygous CARD9 mutation in a family with susceptibility to fungal infections. N Engl J Med. 2006; 361:1727-1735.

106. Aimanianda V, Bayry J, Bozza S, Kniemeyer O, Perruccio K, Elluru SR, Clavaud C, Paris S, Brakhage AA, Kaveri SV, et al. Surface hydrophobin prevents immune recognition of airborne fungal spores. Nature. 2009; 460:1117-1121. [PubMed: 19713928]

107. Hohl TM, Van Epps HL, Rivera A, Morgan LA, Chen PL, Feldmesser M, Pamer EG. Aspergillus fumigatus triggers inflammatory responses by stage-specific beta-glucan display. PLoS Pathog. 2005; 1:e30. [PubMed: 16304610]

108. Steele C, Rapaka RR, Metz A, Pop SM, Williams DL, Gordon S, Kolls JK, Brown GD. The betaglucan receptor dectin-1 recognizes specific morphologies of Aspergillus fumigatus. PLoS Pathog. 2005; 1:e42. [PubMed: 16344862]

109. Gersuk GM, Underhill DM, Zhu L, Marr KA. Dectin-1 and TLRs permit macrophages to distinguish between different Aspergillus fumigatus cellular states. J Immunol. 2006; 176:37173724. [PubMed: 16517740]

110. Goodridge HS, Reyes CN, Becker CA, Katsumoto TR, Ma J, Wolf AJ, Bose N, Chan AS, Magee AS, Danielson ME, et al. Activation of the innate immune receptor Dectin-1 upon formation of a 'phagocytic synapse'. Nature. 2011; 472:471-475. [PubMed: 21525931]

111. Jostins L, Ripke S, Weersma RK, Duerr RH, McGovern DP, Hui KY, Lee JC, Schumm LP, Sharma Y, Anderson CA, et al. Host-microbe interactions have shaped the genetic architecture of inflammatory bowel disease. Nature. 2012; 491:119-124. [PubMed: 23128233] 
112. Marks DJ, Miyagi K, Rahman FZ, Novelli M, Bloom SL, Segal AW. Inflammatory bowel disease in CGD reproduces the clinicopathological features of Crohn's disease. Am J Gastroenterol. 2009; 104:117-124. [PubMed: 19098859]

113. Hayes P, Dhillon S, O’Neill K, Thoeni C, Hui KY, Elkadri A, Guo CH, Kovacic L, Aviello G, Alvarez LA, et al. Defects in NADPH oxidase genes and in very early onset inflammatory bowel disease. Cell Mol Gastroenterol Hepatol. 2015; 1:489-502. [PubMed: 26301257]

114. Dhillon SS, Fattouh R, Elkadri A, Xu W, Murchie R, Walters T, Guo C, Mack D, Huynh HQ, Baksh S, et al. Variants in nicotinamide adenine dinucleotide phosphate oxidase complex components determine susceptibility to very early onset inflammatory bowel disease. Gastroenterology. 2014; 147:680-689. e2. [PubMed: 24931457]

115. Muise AM, Xu W, Guo CH, Walters TD, Wolters VM, Fattouh R, Lam GY, Hu P, Murchie R, Sherlock M, et al. NADPH oxidase complex and IBD candidate gene studies: identification of a rare variant in NCF2 that results in reduced binding to RAC2. Gut. 2012; 61:1028-1035. [PubMed: 21900546]

116. Eglinton TW, Roberts R, Pearson J, Barclay M, Merriman TR, Frizelle FA, Gearry RB. Clinical and genetic risk factors for perianal Crohn's disease in a population-based cohort. Am J Gastroenterol. 2012; 107:589-596. [PubMed: 22158027]

117. Rioux JD, Xavier RJ, Taylor KD, Silverberg MS, Goyette P, Huett A, Green T, Kuballa P, Barmada MM, Datta LW, et al. Genome-wide association study identifies new susceptibility loci for Crohn disease and implicates autophagy in disease pathogenesis. Nat Genet. 2007; 39:596604. [PubMed: 17435756]

118. Roberts RL, Hollis-Moffatt JE, Gearry RB, Kennedy MA, Barclay ML, Merriman TR. Confirmation of association of IRGM and NCF4 with ileal Crohn's disease in a population-based cohort. Genes Immun. 2008; 9:561-565. [PubMed: 18580884]

119. Glocker E, Grimbacher B. Inflammatory bowel disease: is it a primary immunodeficiency? Cell Mol Life Sci. 2012; 69:41-48. [PubMed: 21997382]

120. Yen D, Cheung J, Scheerens H, Poulet F, McClanahan T, McKenzie B, Kleinschek MA, Owyang A, Mattson J, Blumenschein W, et al. IL-23 is essential for T cell-mediated colitis and promotes inflammation via IL-17 and IL-6. J Clin Invest. 2006; 116:1310-1316. [PubMed: 16670770]

121. Zhang Z, Zheng M, Bindas J, Schwarzenberger P, Kolls JK. Critical role of IL-17 receptor signaling in acute TNBS-induced colitis. Inflamm Bowel Dis. 2006; 12:382-388. [PubMed: 16670527]

122. Kristensen NN, Olsen J, Gad M, Claesson MH. Genome-wide expression profiling during protection from colitis by regulatory T cells. Inflamm Bowel Dis. 2008; 14:75-87. [PubMed: 17924563]

123. Fujino S, Andoh A, Bamba S, Ogawa A, Hata K, Araki Y, Bamba T, Fujiyama Y. Increased expression of interleukin 17 in inflammatory bowel disease. Gut. 2003; 52:65-70. [PubMed: 12477762]

124. Duerr RH, Taylor KD, Brant SR, Rioux JD, Silverberg MS, Daly MJ, Steinhart AH, Abraham C, Regueiro M, Griffiths A, et al. A genome-wide association study identifies IL23R as an inflammatory bowel disease gene. Science. 2006; 314:1461-1463. [PubMed: 17068223]

125. Barrett JC, Hansoul S, Nicolae DL, Cho JH, Duerr RH, Rioux JD, Brant SR, Silverberg MS, Taylor KD, Barmada MM, et al. Genome-wide association defines more than 30 distinct susceptibility loci for Crohn's disease. Nat Genet. 2008; 40:955-962. [PubMed: 18587394]

126. Taylor KD, Targan SR, Mei L, Ippoliti AF, McGovern D, Mengesha E, King L, Rotter JI. IL23R haplotypes provide a large population attributable risk for Crohn's disease. Inflamm Bowel Dis. 2008; 14:1185-1191. [PubMed: 18470928]

127. Imielinski M, Baldassano RN, Griffiths A, Russell RK, Annese V, Dubinsky M, Kugathasan S, Bradfield JP, Walters TD, Sleiman P, et al. Common variants at five new loci associated with early-onset inflammatory bowel disease. Nat Genet. 2009; 41:1335-1340. [PubMed: 19915574]

128. Rivas MA, Beaudoin M, Gardet A, Stevens C, Sharma Y, Zhang CK, Boucher G, Ripke S, Ellinghaus D, Burtt N, et al. Deep resequencing of GWAS loci identifies independent rare variants associated with inflammatory bowel disease. Nat Genet. 2011; 43:1066-1073. [PubMed: 21983784] 
129. Iliev ID, Funari VA, Taylor KD, Nguyen Q, Reyes CN, Strom SP, Brown J, Becker CA, Fleshner PR, Dubinsky M, et al. Interactions between commensal fungi and the C-type lectin receptor Dectin-1 influence colitis. Science. 2012; 336:1314-1317. [PubMed: 22674328]

130. de Luca A, Smeekens SP, Casagrande A, Iannitti R, Conway KL, Gresnigt MS, Begun J, Plantinga TS, Joosten LA, van der Meer JW, et al. IL-1 receptor blockade restores autophagy and reduces inflammation in chronic granulomatous disease in mice and in humans. Proc Natl Acad Sci USA. 2014; 111:3526-3531. [PubMed: 24550444] 


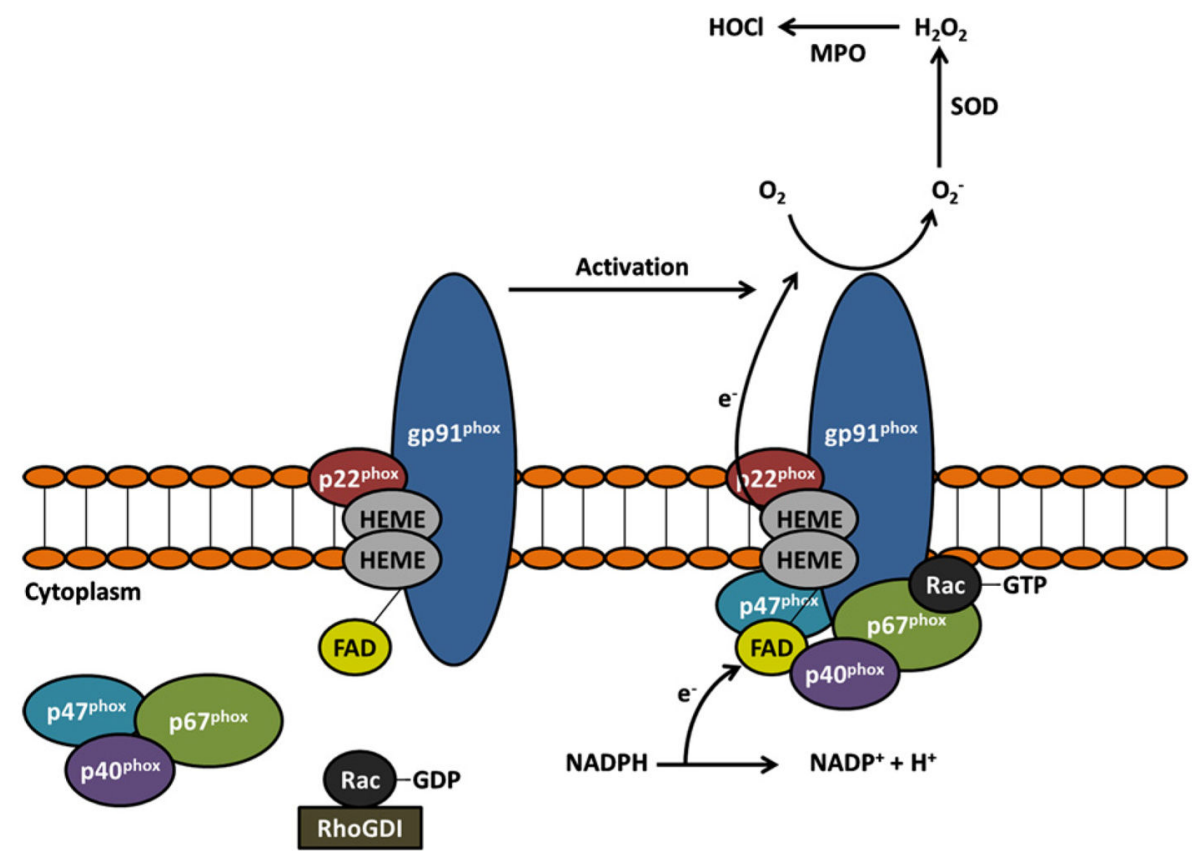

Figure 1. The phagocyte NADPH oxidase (NOX2) is a crucial enzyme in antimicrobial host defence and in regulating inflammation

Activation of NOX 2 requires translocation of the cytoplasmic subunits $\mathrm{p} 40^{\text {phox }}, \mathrm{p} 47^{\text {phox }}$ and p67 $7^{\text {phox }}$ and Rac to the membrane-bound cytochrome comprised of $\mathrm{p} 22^{\text {phox }}$ and gp91 ${ }^{\text {phox }}$. Molecular oxygen is converted to superoxide anion, which can be converted to downstream metabolites with antimicrobial activity, including $\mathrm{H}_{2} \mathrm{O}_{2}$ and hydroxyl anion. In neutrophils, MPO converts $\mathrm{H}_{2} \mathrm{O}_{2}$ to hypohalous acid. 

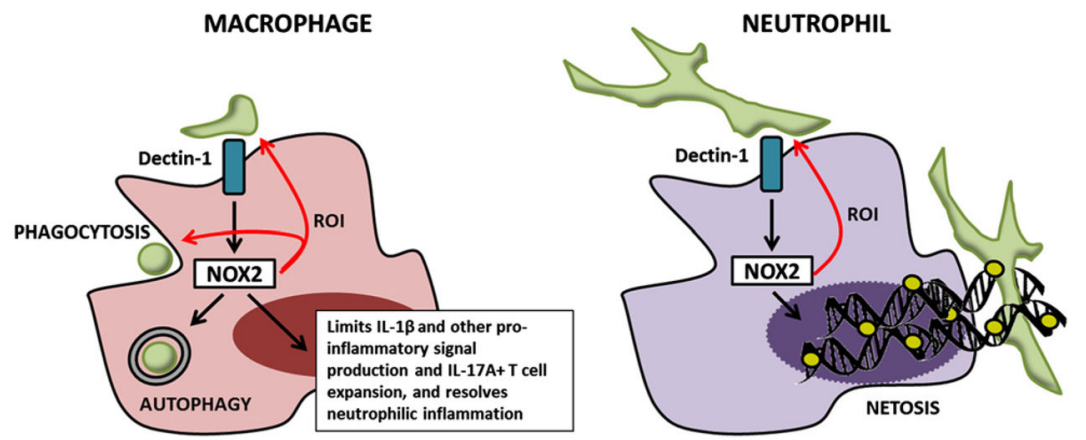

Figure 2. NOX2-mediated antifungal host defence

NOX2 mediates host defence by both ROI generated by the NOX2-halide system, and downstream signalling, including autophagy in macrophages and the generation of NETs in neutrophils. Alveolar macrophages, which are the first line of phagocyte host defence against inhaled fungi, phagocytose and kill Aspergillus spores. Although spores are relatively immunologically inert, exposure of the fungal cell wall component, $\beta$-glucan, during the germling stage activates Dectin- 1 and other PRR. This results in NF- $\kappa$ B activation, production of pro-inflammatory cytokines, and activation of NOX2. Macrophage NOX2 limits the growth of phagocytosed spores and germlings by ROI generation and through activation of autophagy. Autophagy, in addition to its host defence function, limits IL-1 $\beta$. NOX2 in macrophages, and potentially in dendritic cells, can also limit Th17 expansion. Neutrophils principally target the extracellular hyphal stage. NOX2-mediated hyphal injury can occur via direct ROI injury, as well as through NET generation, in which chromatin and granular constituents are released extracellularly. 